\title{
International migration and official migration statistics in Hungary
}

Lajos Bálint The challenges that official migration statis-

Hungarian Demographic

Research Institute

E-mail: balint@demografia.hu

Zoltán Csányi

Hungarian Central

Statistical Office

E-mail: Zoltan.Csanyi@ksh.hu

Máté Farkas

Hungarian Central

Statistical Office

E-mail: Mate.Farkas@ksh.hu

\section{Hajnalka Hluchány}

Hungarian Central

Statistical Office

E-mail: Hajnalka.Hluchany@ksh.hu

\author{
Áron Kincses \\ Hungarian Central \\ Statistical Office \\ E-mail: Aron.Kincses@ksh.hu
} tics face in the $21^{\text {st }}$ century are manifold. In line with intensifying globalisation processes, and new patterns and types of migration, new routes and new migrant identities have been emerging. However, the new trends also offer new, potentially usable data sources, tools, and methods for the measurement of this changing phenomenon. Attempting to provide an overview of the Hungarian migration statistical system, the aim of this paper is to promote interdisciplinary scientific dialogue on migration and share some of the most important figures and trends of international migration in Hungary, highlighting its remarkable geographical aspects in the European context, and the peculiarities, challenges, and opportunities of its measurement.

Keywords:

migration statistics,

Hungary, population, network analysis, neighbourhoods

\section{Introduction}

Geographical movements characterise humanity from the very beginning of its history. However, as the United Nations' New York Declaration for Refugees and Migrants adopted in 2016 affirms 'we are witnessing in today's world an unprece-

Regional Statistics, Vol. 7. No. 2. 2017: 101-123; DOI: 10.15196/RS070203 
dented level of human mobility. More people than ever before live in a country other than the one in which they were born. [...] In 2015, their number surpassed 244 million, growing at a rate faster than the world's population.' (UN General Assembly 2016 p. 2.) Intentions - mainly in population-, labour market-, and social cohesion policy-making - to reduce undesired negative effects of human mobility or to harvest potential benefits, making the best of it, have become central topics in hot-tempered political debates and public discourses on future socio-economic and demographic developments of both sending and receiving societies.

Corresponding to opposing theoretical approaches ${ }^{1}$, greater discussion emerged on the relations of migration and development that determined both related policy debates and research. ${ }^{2}$ In this context, the relevance of producing high-quality official statistics on migration-related phenomena that provides inputs indispensable for contrasting hypotheses - that is for theory construction and for making well-designed policies is undeniable. Not even the tendency of the relationship of policy-making and scientific knowledge that leads through the phases of 'evidence-based' and 'evidence-informed' policies to 'post-truth' policymaking minimises this relevance. The counter-trend of an increasingly stronger desire and efforts of the scientific society to have a voice in migration policymaking is manifested by the fact that increasingly more research centres and projects position themselves as government capacity builders. ${ }^{3}$ Despite the efforts, the warning of De Jong and Gardner (1981) from almost four decades - that 'the difficulty in implementing policies designed to alter migration behaviour in the absence of theoretically sound and empirically validated models of such behaviour is apparent' - is still as actual as it was in its time.

However, the lack of empirically validated theoretical models and the weakening impact of scientific research on migration policy decision-making are not the only challenges that official statistics face. The phenomenon and related aspects - that we try to measure and understand - is changing over time. Massey et al. (1998) described how migration phenomena had been changing over the last century and lamented that the concepts used for analysing them in the millennium were products of the industrial era. Changes, such as intensifying socio-economic trends of the globalising world, global markets, global media and communication, and cheaper and faster global transportation, affect not only migration decision-making processes, but have also created increasingly newer migration routes, patterns of migration

\footnotetext{
${ }^{1}$ For a review of migration theories, see for example De Haas (2008).

2 On the migration-development nexus (or migration-development mantra), see for example Castles-Delgado Wise (2008), Castles (2008), Faist (2008), etc.

${ }^{3}$ See for example the government capacity building activities of the IOM's (International Organization for Migration) Global Migration Data Analysis Centre at http://gmdac.iom.int/capacity-building-search or the ongoing Danube Region youth migration project, YOUMIG - Improving institutional capacities and fostering cooperation to tackle the impacts of transnational youth migration at http://www.interreg-danube.eu/approvedprojects/youmig
}

Regional Statistics, Vol. 7. No. 2. 2017: 101-123; DOI: 10.15196/RS070203 
behaviour, migrant types, and identities. Circular or multiple movements, commuting, multilocation - merely to mention a few - have gained importance in migration literature (see e.g. Tannenbaum 2007, Illés 2008, Illés et al. 2009, Skeldon 2012, Mc Loughlin et al. 2011, McHugh 1995, Egedy 2017). As a result, more than ever, a dynamic and inter-disciplinary theoretical framework is needed that considers geographical mobility and development both at the micro and macro levels from an interdisciplinary point of view.

In parallel with the transformation of migration phenomena, new types of data sources have also become available for statistical use that yield in the development of the tools and methods of measuring and analysing migration. The general use of administrative data sources in the production of official statistics - and the potential benefits of using Big Data - involves the constant improvement of data integration techniques, making possible the creation of new, internally and externally coherent, high-quality data sets for the joint analysis of variables not jointly observed previously. A detailed overview of the methodological improvements or the possibilities for theory making is out of the scope of this paper. Instead, this paper - focusing exclusively on international, voluntary, and documented migration flows - reflects the attempt of its authors to promote scientific dialogue on migration, sharing on one hand some of the figures and trends of international migration in Hungary highlighting its remarkable geographical aspects in the European context, and the peculiarities of its measurement in the Hungarian statistical system on the other. By doing so, first, some details of the European migration context will be outlined in which Hungarian migration processes take place. Second, the patterns and some of the most important geographic aspects of international migration in Hungary will be traced. This will be followed by a description of the official migration statistics production system of the Hungarian Central Statistical Office (HCSO). Finally, some concluding remarks close the paper.

\section{Migration context in Europe}

Due to decreasing tendencies in childbearing, for decades, developed European Union (EU) countries have been facing the demographic challenges of negative natural changes and the consequent aging of the population (Salt 2001). As an illustration, see Figure 1 that shows that the fertility rates of European countries are below the reproduction level, and Figure 2 that depicts the threats of population aging by comparing the share of elderly people $(65+)$ in European societies as in 2016 and as projected for the year 2050.

Regional Statistics, Vol. 7. No. 2. 2017: 101-123; DOI: 10.15196/RS070203 
Total fertility rates in European countries, 2015

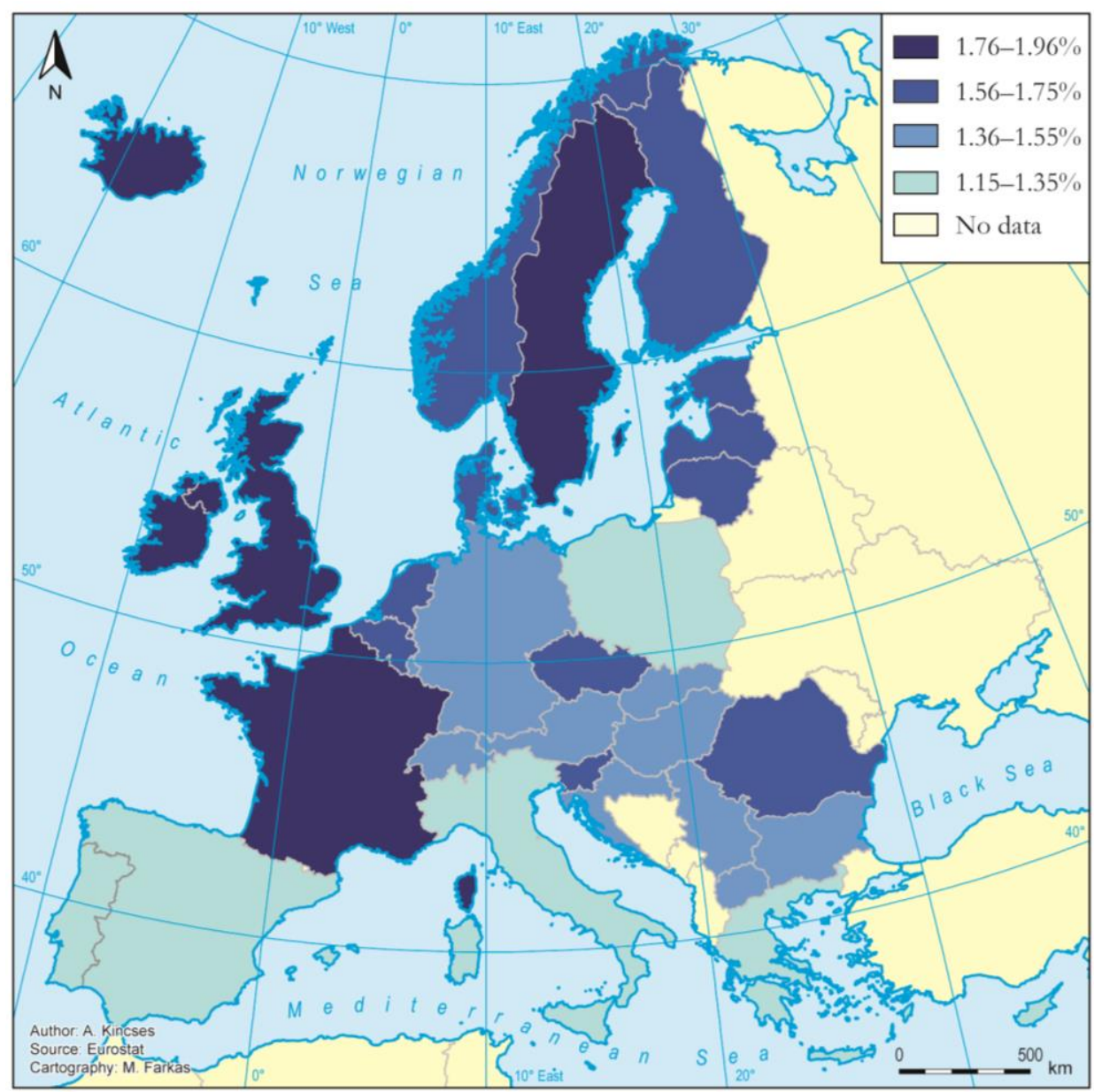

Source: Eurostat database. 
Figure 2

Share of the elderly population (aged 65 and older) in European countries

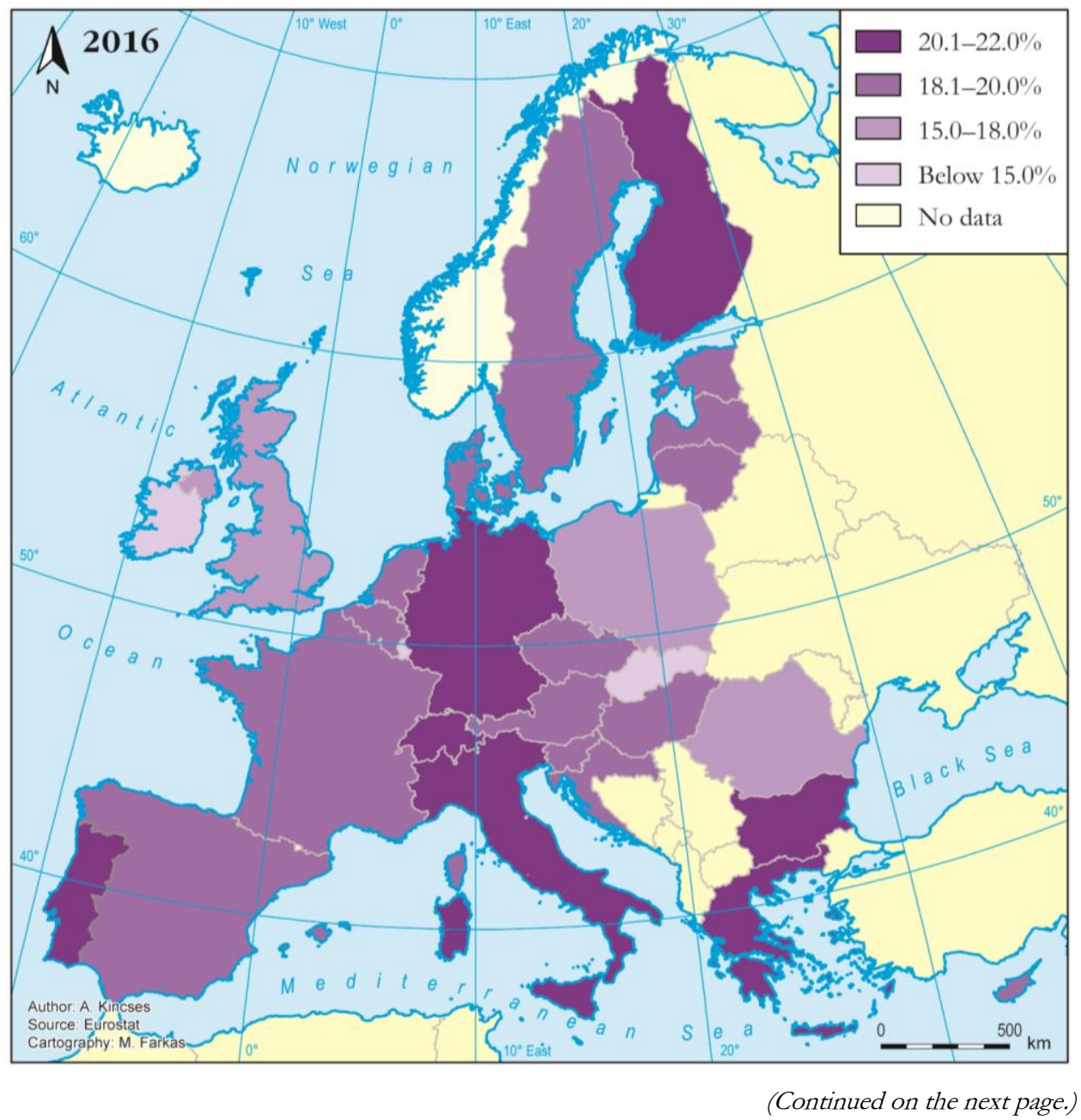

Regional Statistics, Vol. 7. No. 2. 2017: 101 -123; DOI: 10.15196/RS070203 


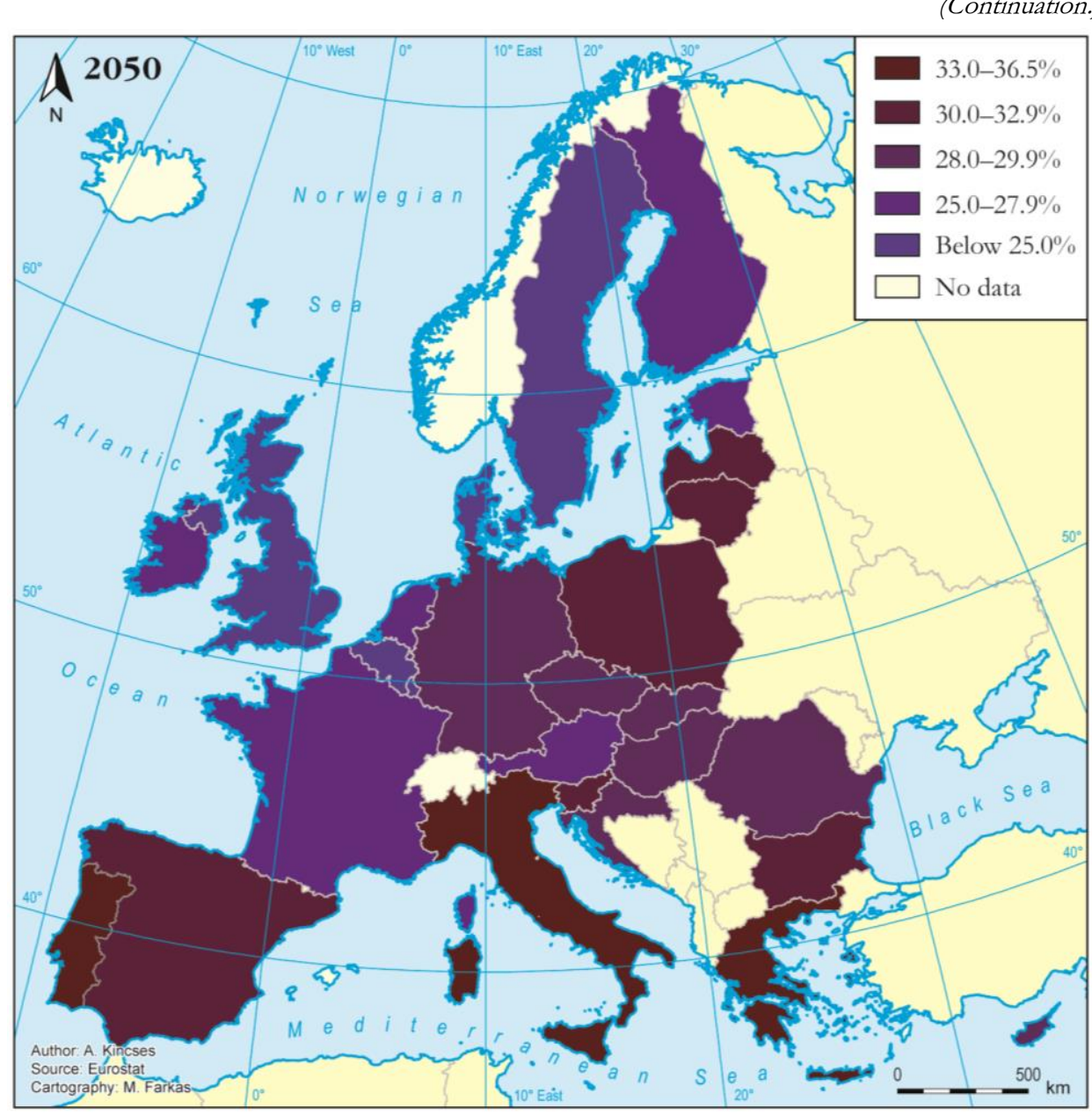

Source: Eurostat database.

It should be added here that in parallel - and in relation - with the abovementioned tendencies of population ageing, the patterns of emigration from Europe have also changed. This is rather well illustrated by the decreasing relative share of European-born population in the United States. As it can be observed in Figure 3, the significance of European emigration to the United States has been falling since the last half century (while simultaneously, the share of those born in developing countries has been increasing).

As regards intra-European movements, the free movement of persons within the Schengen territory in recent decades - that has made crossing internal borders easier in Europe - serves the aims of mitigating the inequalities and labour market disequi-

Regional Statistics, Vol. 7. No. 2. 2017: 101-123; DOI: 10.15196/RS070203 
libria in member states and creates a peculiar situation in which migrating European and third-country citizens are distinguished, and their rights and possibilities are distinct. Indeed, the decreasing and aging population in the most developed Northern and Western-European countries resulted in labour shortages, and in a consequent replacement of migration and recruitment of foreign workers from less developed European or developing third countries (Hatton et al. 2005, Gellérné et al. 2005). Figure 4 shows how the relative share of EU-born foreign population in the total foreign population is varying across European countries in accordance with the type of dominant immigration flows in each of them, that is, whether in a given EU member state, intra-European movements or inflows of third-country nationals are predominant.

Figure 3

\section{Relative share of foreign-born population in the United States, by continent}

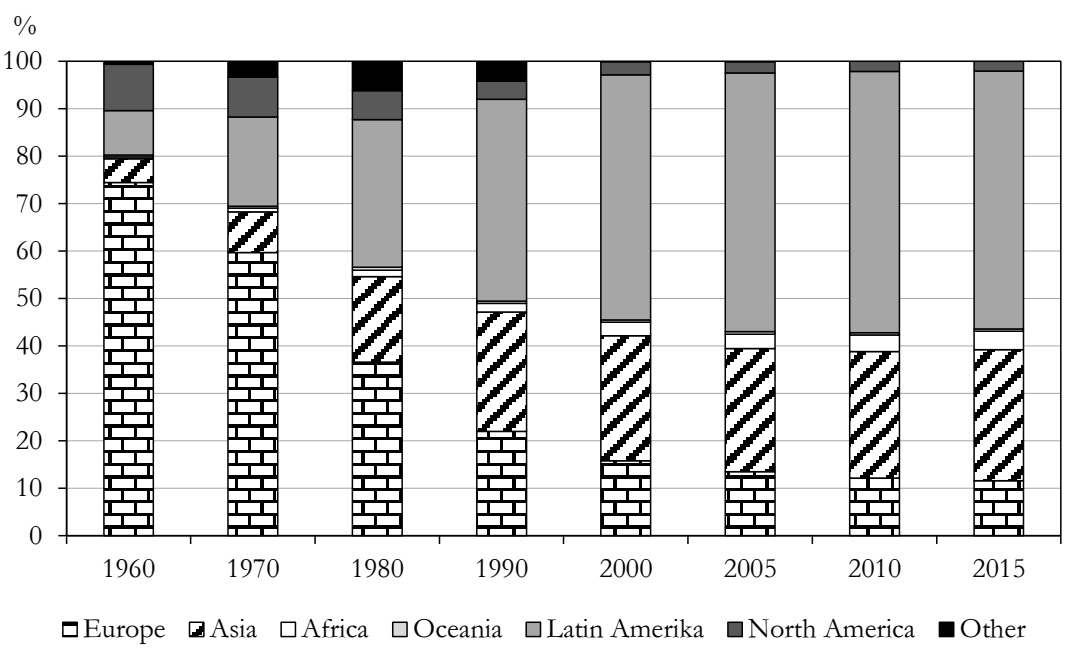

Source: United Nations database. 
Share of EU-born foreign population in the total foreign population of

Figure 4 European countries, 2016

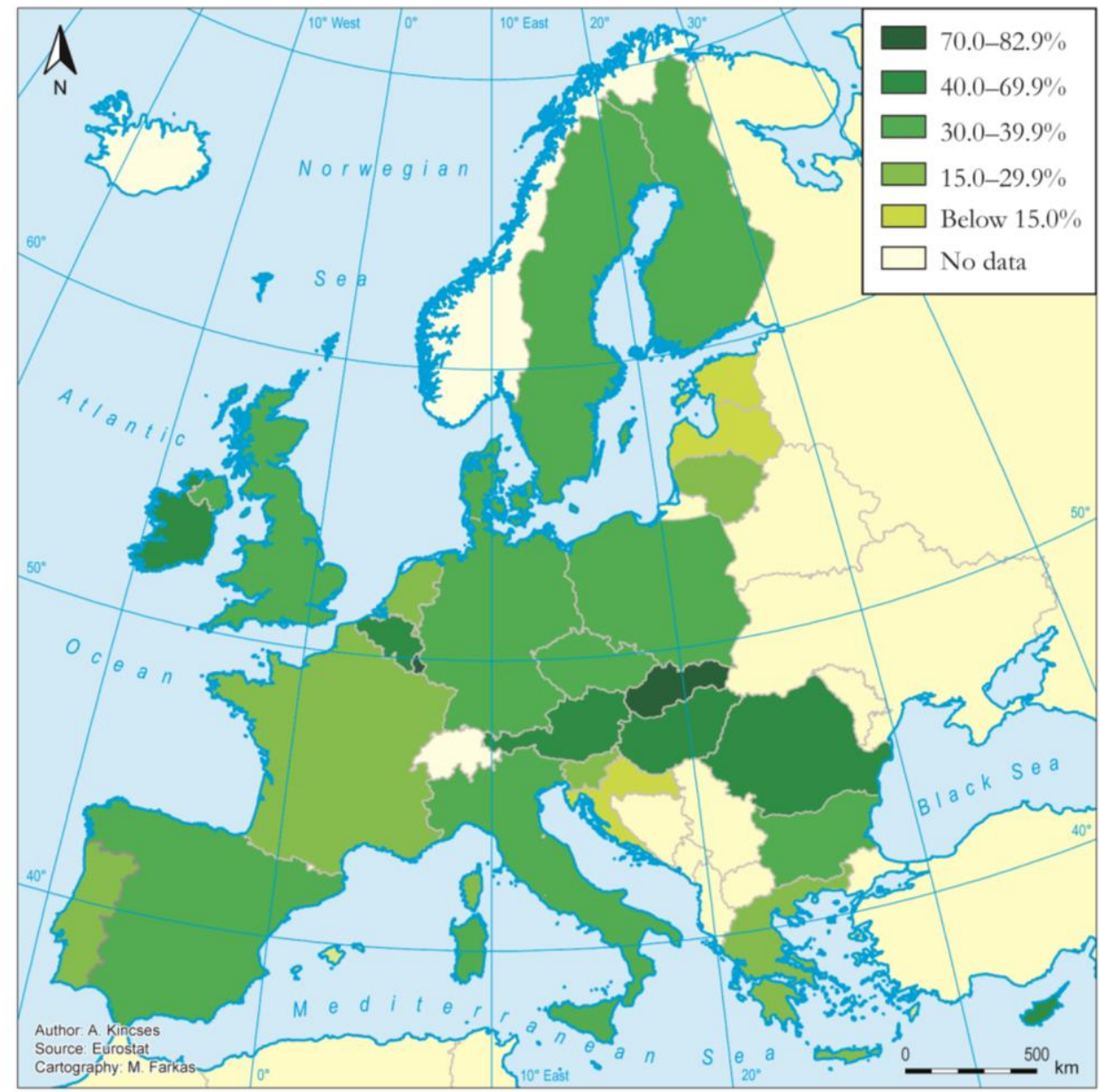

Source: Eurostat database.

Focusing on immigration from third countries, as the global population projections suggest, the relative share of developing countries in the world's population in comparison to that of more developed ones will further increase (Cohen 2006). Over-population, together with growing income gaps and the imbalanced development of the world's countries (Kofman 2003), encourage the geographical movements from all over the world (Hatton et al. 2005), making Europe a popular destination among migrants from other continents. Furthermore, migration decisionmaking is also affected by trends of a globalising world as the rapid development of 
transportation and telecommunication technology make relocation cheaper and easier, reduce economic and psycho-social costs of moving, and help potential migrants to access more trustable and up-to-date information on destinations. As a result, a rising awareness is observable in migration decision-making.

Overall, in parallel with the increasing accessibility to global markets and high wage areas (Williamson 2006), over the past decades, the migration role of Europe (as a host area) has been revaluated (Venables 1998, Gábrity 2006, Kincses 2012, Kincses 2015). Nowadays, most Western and Northern European countries have a foreign-born population of several million. Since the regime changes of the 1990s in Central and Eastern European countries, as a result of economic integration, they have also become host areas to migrant population (Traistaru et. al. 2002) (for the share of foreign citizens in EU countries, see Figure 5).

\section{Share of foreign citizens in the population of EU countries, 2016}

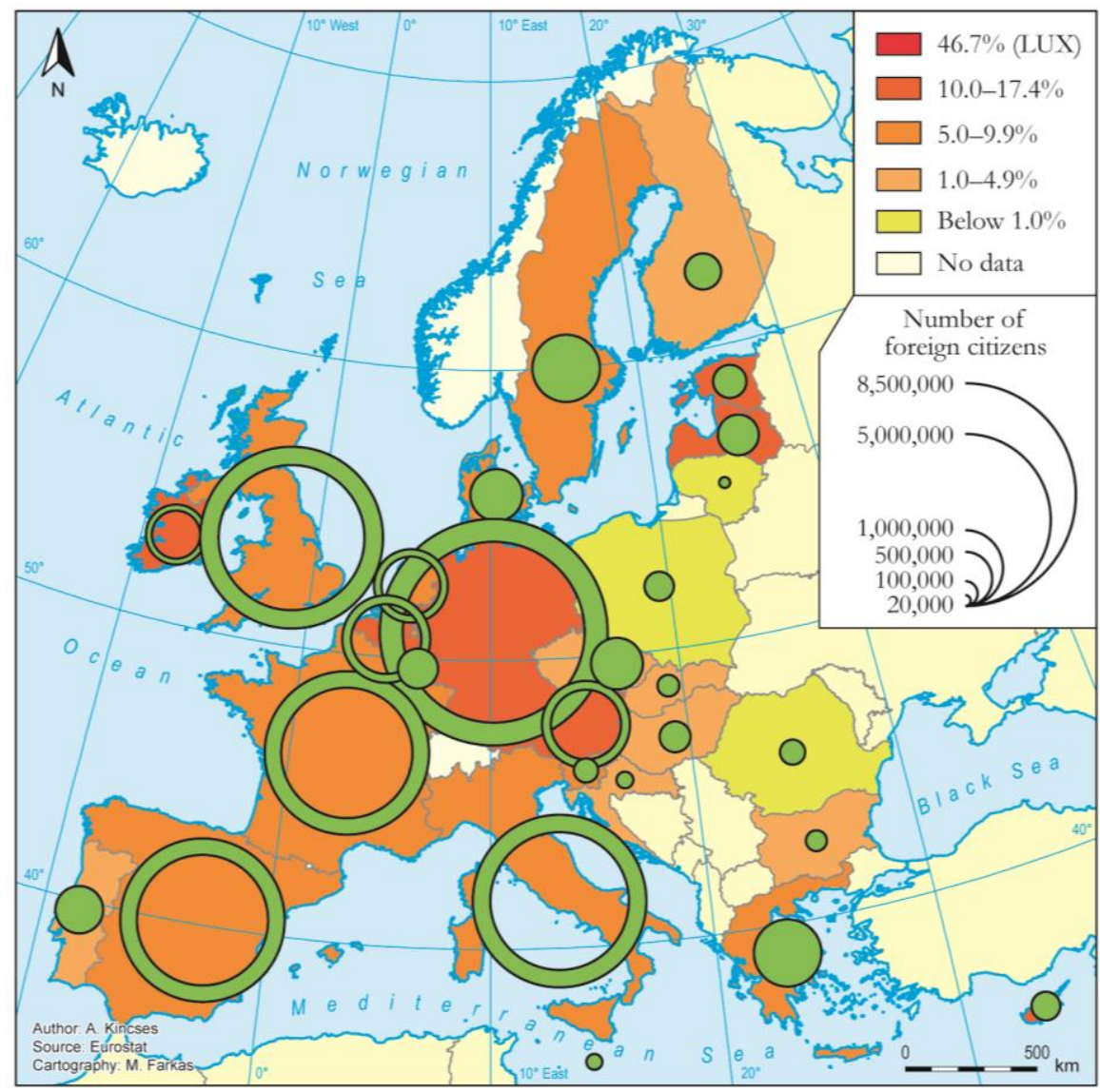

Source: Eurostat database.

Regional Statistics, Vol. 7. No. 2. 2017: 101-123; DOI: 10.15196/RS070203 


\section{International migration in Hungary}

Hungary, like other countries in Central Europe, has become a target, mostly for migrants from other European countries (Tóth 2005, Hárs 2009, Hárs-Simon 2015). However, the source areas are expanding constantly: Hungary nowadays hosts citizens from 168 countries, thus it has become part of the global route. An important feature of international immigration in Hungary is that due to simplified naturalisation procedures for ethnic Hungarians in neighbouring countries, migration data by citizenship 4 and by country of birth strongly differ. As the table shows, while the number of foreign citizens ${ }^{5}$ residing in Hungary was 150,000 in 2016, the foreign-born population ${ }^{6}$ was 380,000 (approximately 4\% of the total population).

\section{Number of foreign citizens and foreign-born population in Hungary}

\begin{tabular}{l|r|r|r|r|r|r}
\hline \multirow{2}{*}{$\begin{array}{l}\text { Country of citizenship/ } \\
\text { country of place of birth }\end{array}$} & \multicolumn{2}{|c|}{2001} & \multicolumn{2}{c|}{2011} & \multicolumn{2}{c}{2016} \\
\cline { 2 - 7 } & Foreign & $\begin{array}{r}\text { Foreign- } \\
\text { born popu- } \\
\text { lation }\end{array}$ & $\begin{array}{r}\text { Foreign } \\
\text { citizens }\end{array}$ & $\begin{array}{c}\text { Foreign- } \\
\text { born popu- } \\
\text { lation }\end{array}$ & $\begin{array}{c}\text { Foreign } \\
\text { citizens }\end{array}$ & $\begin{array}{c}\text { Foreign- } \\
\text { born popu- } \\
\text { lation }\end{array}$ \\
\hline Total & 93,005 & 283,951 & 143,197 & 383,236 & 149,111 & 383,495 \\
Of which: & 35,558 & 141,191 & 38,574 & 176,550 & 21,738 & 158,020 \\
Romania & 10,195 & 22,481 & 11,820 & 35,354 & 4,966 & 37,121 \\
Ukraine & 4,213 & 36,382 & 8,246 & 33,155 & 17,051 & 32,843 \\
Slovakia & 8,920 & 26,060 & 7,752 & 29,144 & 3,038 & 25,387 \\
Serbia & 1,086 & 3,540 & 3,936 & 6,160 & 4,475 & 5,978 \\
Austria & 1,246 & 4,323 & 845 & 3,498 & 1,042 & 2,605 \\
Croatia & 84 & 674 & 252 & 657 & 323 & 820 \\
Slovenia & 5,674 & 9,841 & 16,987 & 22,605 & 19,517 & 23,453 \\
Germany & 4,057 & 3,825 & 8,852 & 8,767 & 13,279 & 12,308 \\
China & 2,630 & 6,393 & 2,512 & 6,690 & 4,408 & 8,687 \\
Russia & 835 & 1,081 & 2,602 & 3,597 & 4,334 & 5,646 \\
United Kingdom & 1,588 & 2,355 & 3,022 & 4,684 & 3,523 & 5,042 \\
United States & & &
\end{tabular}

Source: HCSO (Census 2001, 2011, and Microcensus 2016) data.

It should be added that while in 2001, the share of foreign citizens from neighbouring countries in the total foreign population was $66 \%$, by 2016 it decreased to

\footnotetext{
${ }^{4}$ Ethnic Hungarians in neighbouring countries who obtain Hungarian citizenship are automatically considered as Hungarian citizens. On their immigration to Hungary, see for example Kósa (2016).

5 The foreign population consists of people who still have the nationality of their home country.

${ }^{6}$ The foreign-born population covers all people who have ever migrated from their country of birth to their current country of residence.
}

Regional Statistics, Vol. 7. No. 2. 2017: 101-123; DOI: 10.15196/RS070203 
$5 \%$. The largest decrease occurred among the Romanian (by 24 percentage points), the Ukrainian, and the Serbian citizens (both by 8 percentage points). The decrease was smaller among people born in the neighbouring countries (from $83 \%$ to $69 \%$ ). The main reason for this is the simplified naturalisation procedure that came into force in Hungary in 2011. Between 2011 and 2016, almost 62,000 ethnic Hungarians acquired Hungarian citizenship from the neighbouring countries, most of which were Romanian (79\%), Ukrainian (10\%), and Serbian (7\%) citizens.

On the other hand, regarding the measurement of national Hungarians abroad, a certain level of uncertainty is apparent. ${ }^{7}$ The use of administrative data sources for estimating emigrant stocks and flows is often criticised since migrants tend not to de-register, thus the results based on registers necessarily underestimate outmigration. Estimations based on different data sources increase this uncertainty considerably more. According to expert estimations (Gödri 2010, Kapitány et al. 2013), the stock of Hungarian emigrants is between 300,000 and 650,000. Using mirror statistics, ${ }^{8}$ this number is 595,000 . However, mirror statistics - biased by the fact that many emigrants return to their home countries (Horváth 2016) - presumably overestimate real outmigration. As Figure 6 illustrates, the number of returners in Hungary is rapidly growing: more than 10,000 Hungarians have returned home annually since 2013 .

Figure 6

\section{Returning Hungarian citizens}

\section{Number of}

persons

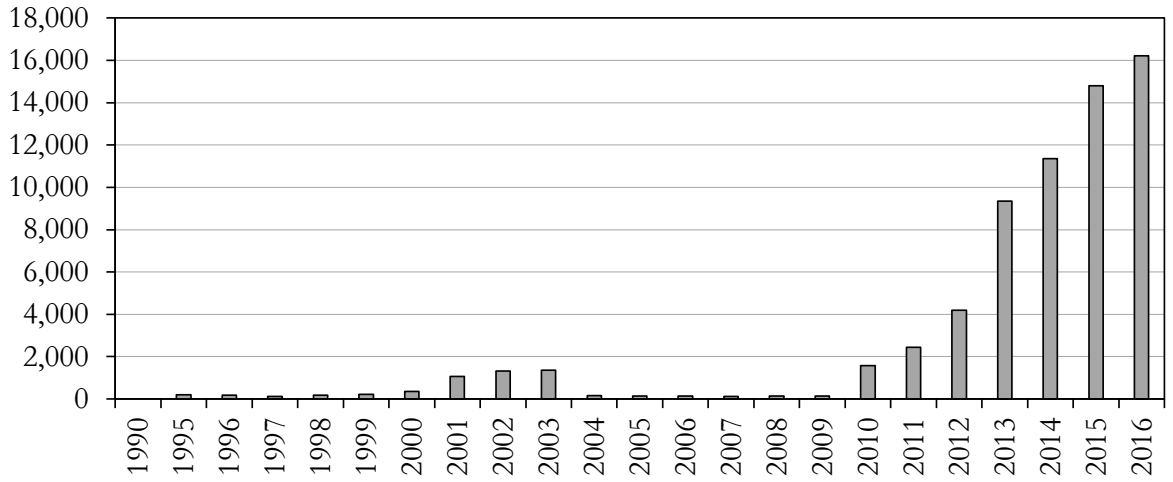

Source: HCSO migration database.

7 On the emigration of Hungarian citizens, see for example SEEMIG (2014), Blaskó-Ligeti-Sik (2014), Blaskó (2014), Hárs (2016), and Moreh (2014). On the emigration intentions, see Sik-Örkény (2003), Sik-Szeitl (2016) and Siska-Szilasi-Kóródi-Vadnai (2016).

${ }^{8}$ United Nations, Department of Economic and Social Affairs (2015). Trends in International Migrant Stock: Migrants by Destination and Origin (United Nations database, POP/DB/MIG/Stock/Rev.2015).

Regional Statistics, Vol. 7. No. 2. 2017: 101-123; DOI: 10.15196/RS070203 
Returning to the question of estimating emigration, our own research, carried out in the framework of the SEEMIG ${ }^{9}$ project in 2014, calculated the stock of Hungarian emigrants based on the following usage and reconciliation of three different data sources:

a) A SEEMIG pilot survey was conducted as a complementary module of LFS (labour force survey), in which resident household members were asked on other household members and relatives, aged 15-74, residing abroad. The survey found, among others, that $88 \%$ of the emigrant population aged $15-74$ belongs to the age group 18-49, that at least $81 \%$ of the emigrant population left the country more than 1 year before data collection, and that at least $20 \%$ of those who left the country more than 1 year before residing outside the EU.

b) A complementary module was introduced in the Hungarian Demographic Research Institute's Turning Points of Life Course survey that provided the opportunity to check the Central Population and Address Register of Hungary, that is, whether registered persons do reside at the address indicated in the register or not. According to the results, 335,000 registered citizens aged 18-49 resided abroad in 2013.

c) Using mirror statistics from Eurostat and the UK Population Survey, it was estimated that 280,000 Hungarian citizens lived in European countries.

SEEMIG experts developed two methods that combined a) and b), and a) and c) data sources respectively, and the results from both were consistent with each other: in 2013, approximately 350,000 Hungarians - who left the country between 1989 and 2012 - lived abroad.

\section{Geographical aspects of immigration in Hungary}

The following two maps indicate the number of foreign citizens per 100 inhabitants by settlements in 2004 and 2016. The rate increased from 2004 to 2011, and in 2012, it declined owing to the new regulation coming into force on simplified naturalisation in Hungary. In this year, approximately 40,000 foreigners obtained Hungarian citizenship and fell out of the scope of the foreigners. After this period, from 2013, the number and rate of migrants increased again.

9 SEEMIG is a strategic project funded by the European Union's South-East Europe Programme. www.seemig.eu

Regional Statistics, Vol. 7. No. 2. 2017: 101-123; DOI: 10.15196/RS070203 
Figure 7

Share of foreign citizens in the Hungarian population, by settlement
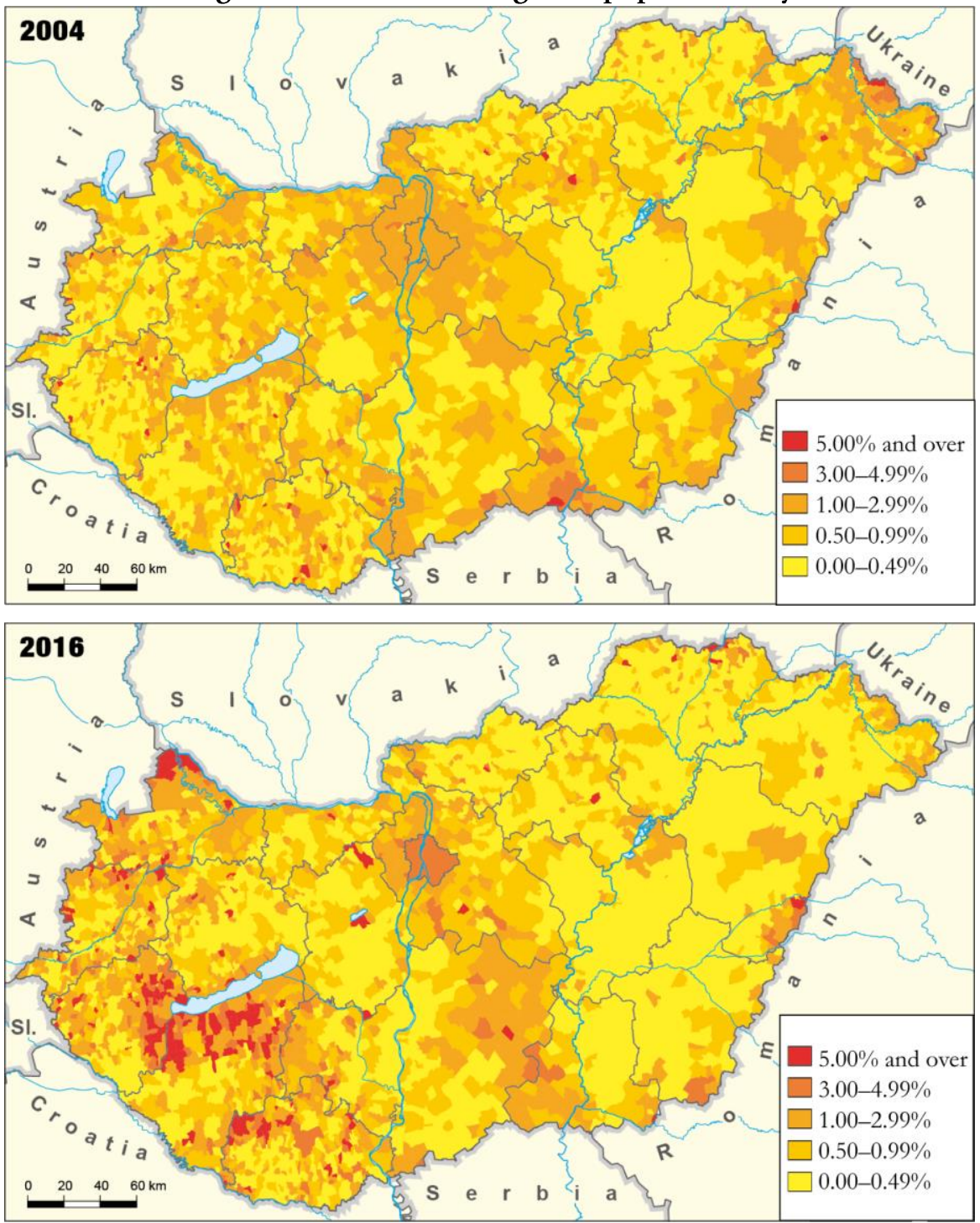

Source: HCSO migration database.

The following tree areas have risen significantly:

- The first is Budapest (and Pest county), the capital city of Hungary, which is a global destination for migrants (Köszeghy 2010). Each second foreigner in Hungary has chosen Budapest. The farther the migrants come from, the more the capital city becomes the number one destination. 58\% Africans, 77\%

Regional Statistics, Vol. 7. No. 2. 2017: 101 -123; DOI: 10.15196/RS070203 
Asians, and 56\% Americans live in the capital. In Budapest, 5\% of the taxpayers are non-Hungarian citizens.

- The second area is the surroundings of Lake Balaton. Retired immigrants are concentrated here (Illés et al. 2008). Most of them come from EU15 countries. Elderly individuals' migration to Hungary, mostly to small villages, is a new profile in the migration statistics.

- The third area includes settlements along the border, which is not a barrier, but rather a contact zone (Anderson et al. 1999, Hansen 1977, Nijkamp 1998, Van Geenhuizen et al. 2001).

These findings are supported by the following map, which illustrates the settlements of Hungary, according to the highest number of foreign nationals living there. We can observe typical connected groups on the map by citizenship. Foreign citizens along the border mostly come from the other side of the border (as we can see in the case of Ukrainian citizens, marked in purple or in the case of Slovakian citizens marked in blue), while Lake Balaton is mostly red, indicating German citizens. The most considerable group of foreign citizens is Romanians in Hungary marked by yellow.

Figure 8

Settlements of Hungary by the nationality of foreign citizens living there in the largest number, 2016

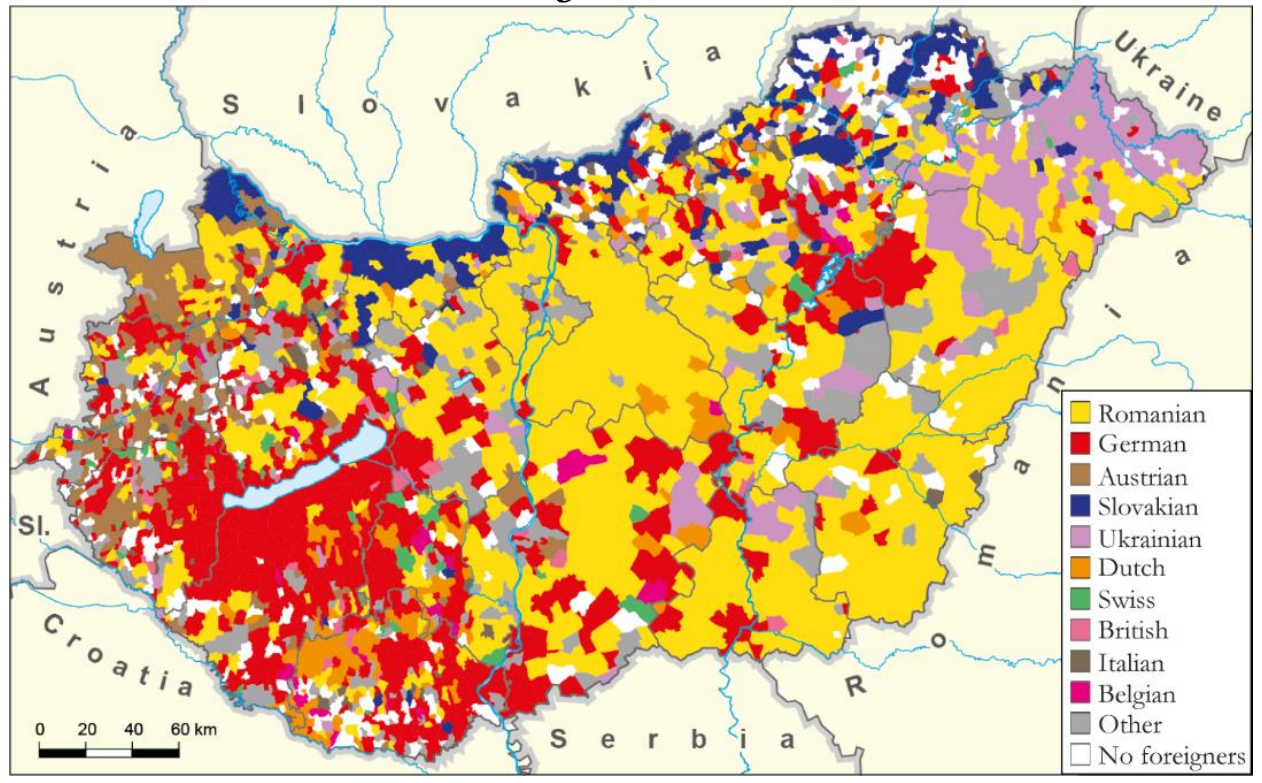

Source: HCSO migration database. 
One of the most important analytical potential of Hungarian migration statistics is the fact that we can identify the foreigners' settlement of origin. We can demonstrate it using the most prominent group of foreign citizens in Hungary.

The largest population of Hungarian ethnicity outside Hungary lives in Romania. In 1992, 7.1\% of Romania's population identified themselves as Hungarian. This figure was $6.7 \%$ in 2002, while $6.1 \%$ in 2011. The proportion of Hungarians living in Transylvania, Banat, and Partium is $18 \%$. More than half of the Hungarians in Romania live in Székely Land. Besides Transylvania, a significant number of Hungarians in Romania live in Csángó Land and Bucharest (Kapitány et al. 2013). Belonging to the ethnicity has long played an important role in international migration characteristics between the two countries. The Hungarian characteristic of international migration is that parts of the foreign citizens have a Hungarian mother tongue. The intensity of cross-border linguistic and cultural links is mainly the consequence of peace treaties ending World War I and II. This determinism is continuously decreasing, but still dominant.

Romanian-Hungarian migration relations are traditionally strong. According to census data, 38,600 Romanian citizens lived in Hungary (as of 1 October 2011), and 176,600 people born in Romania settled into Hungary. By 2016, the number of both groups decreased marginally: to 21,700 and 158,000 , respectively. International migration between the two countries affects all Romanian and Hungarian counties. This means that migrants come to Hungary from each Romanian county, while Romanian migrants can be found in all Hungarian counties.

Figure 9

Romanian citizens living in Hungary, by 'sending' settlement, 2016

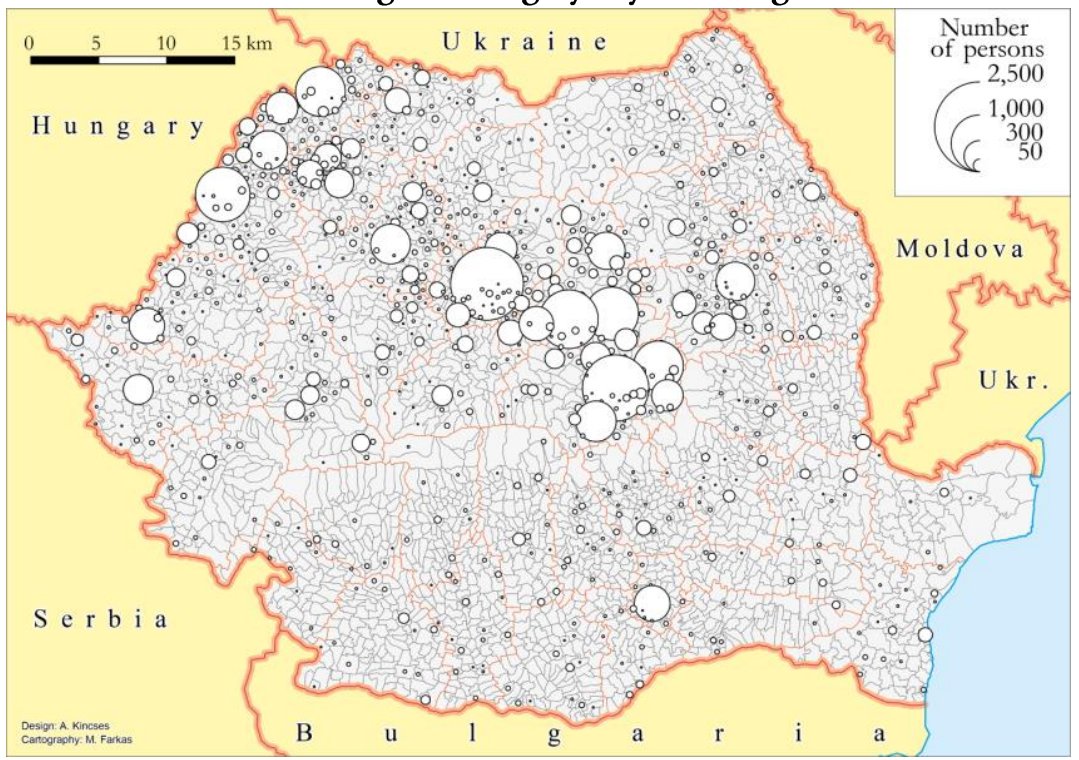

Source: HCSO migration database.

Regional Statistics, Vol. 7. No. 2. 2017: 101 -123; DOI: 10.15196/RS070203 
The most affected Romanian counties in the migration to Hungary are Harghita (3,588 people), Mures (3,240 people), Covasna (3,090 people), Bihor (2,117 people), Satu Mare (1,524 people), Bacau (1,387 people), and Cluj (1,116 people). A significant number of Hungarian minorities live in these areas. Approximately $66 \%$ of the foreign citizens coming to Hungary come from these seven counties.

This result allows us to take the geographical 'from-to' matrix type approach (Kincses-Bálint 2016). We can examine the relationship between the place of origin and current locations. The next flow maps present the foreign citizens staying in Hungary from neighbouring countries at regional level. These are stock type of data, and the arrows link together the origin and current regions.

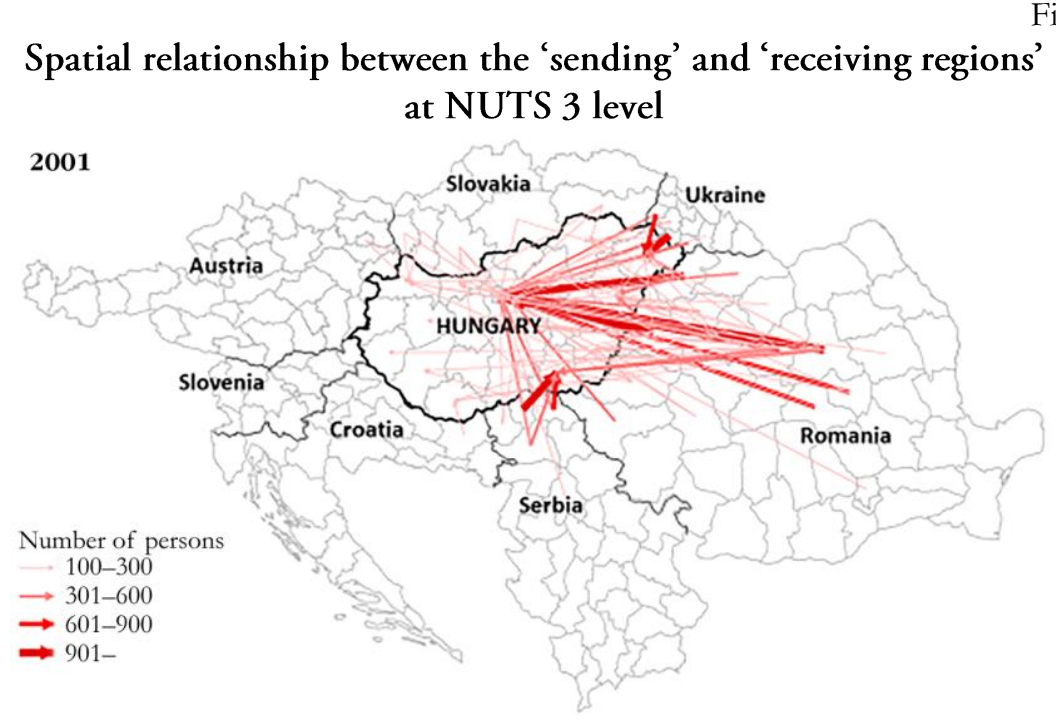

2016

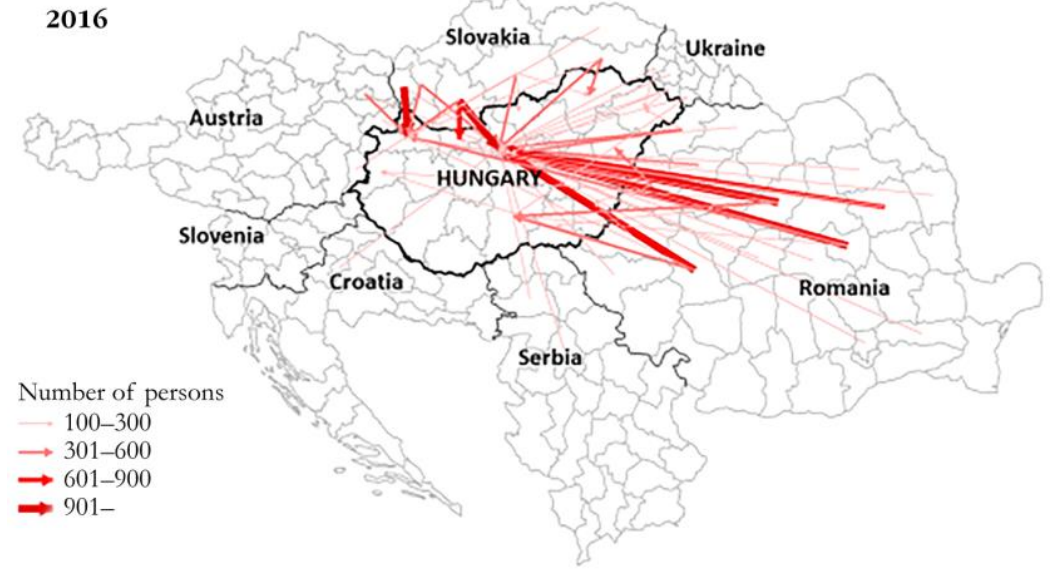

Source: HCSO migration database.

Regional Statistics, Vol. 7. No. 2. 2017: 101-123; DOI: 10.15196/RS070203 
Budapest is clearly the centre of international immigration in Hungary, but other regional hubs have gained importance as a destination in the meantime. Migration directions have shifted to the west and north. If we further specify our examination according to the educational level, we can identify that with the increase of skills and capabilities, migration becomes more concentrated in the economic centre areas, such as Budapest and other developed regional cities (Rédei 2007).

\section{Producing official migration statistics in Hungary}

Before attempting to briefly describe the Hungarian migration data production system, some clarifications should be made (see also Gárdos-Gödri 2013, SEEMIG 2014). First, the migration statistical system in Hungary forms part of the population statistical system, and migration data - beyond the data that refer to the natural population changes - are used for census-based population estimations. Second, as it was mentioned in previous sections of this paper, due to the high number of ethnic Hungarians in neighbouring countries and the simplified naturalisation processes for them, a sharp distinction of migration processes by citizenship and country of birth is required. Third, migration data are produced on the basis of administrative data sources (see Figure 11), and all phases of data production - from data transmissions between data owners and the HCSO to data processing and analyses - are carried out in the HCSO's integrated information technology applications.

\section{Population statistics in Hungary}

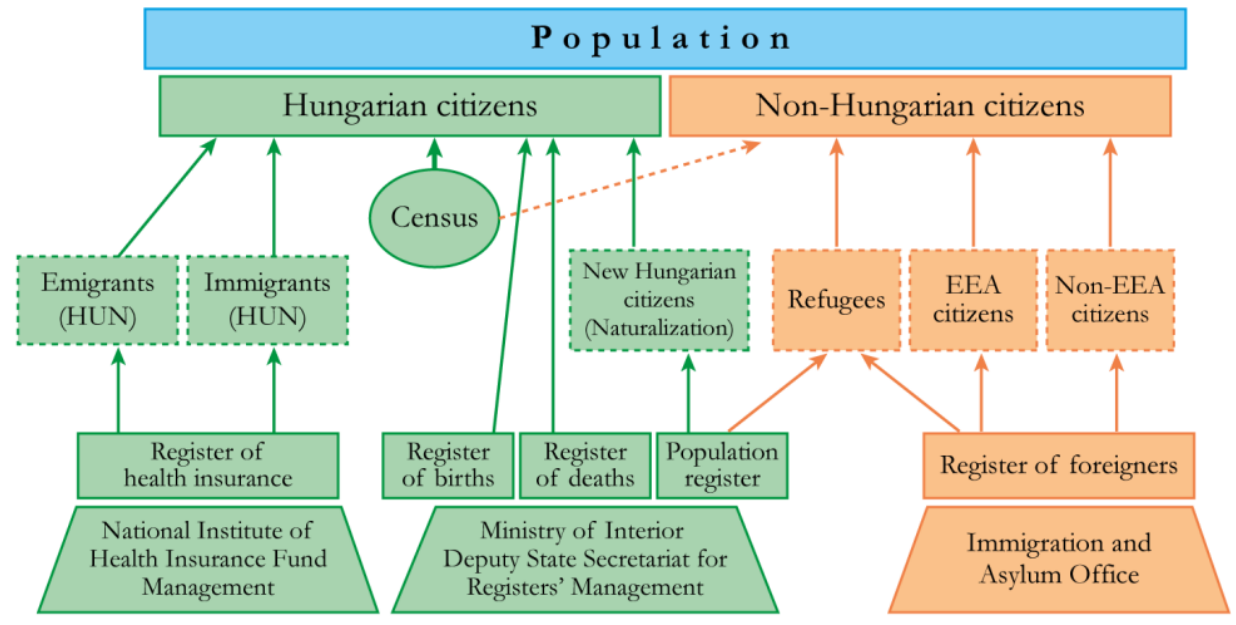

Note: EEA - European Economic Area.

Source: Own elaboration.

Regional Statistics, Vol. 7. No. 2. 2017: 101 -123; DOI: 10.15196/RS070203 
Data on the following migration types are produced in the Hungarian migration statistical system:

- International immigration of foreign citizens: inflows and stocks of both European Economic Area (EEA) and non-EEA citizens in Hungary are calculated on the basis of the respective sub-systems of the Register of Foreigners, owned by the Immigration and Asylum Office. There is also data available in this register on asylum seekers (however, they are not considered in population estimates) and refugees (that also appear in the Population Register of the Ministry of Interior).

- International emigration of foreign citizens: outflows of EEA and nonEEAcitizens are calculated separately using the formerly mentioned subsystems of the Register of Foreigners. Residence documents issued by the Immigration and Asylum Office for non-EEA citizens expire, thus providing a crucial input for producing data on their outflows. Contrarily, residence documents of EEA citizens do not expire, thus data on their outflows are estimations.

- The international immigration of Hungarian citizens refers on one hand to the naturalised ethnic Hungarians born abroad and to returners on the other. Flow and stock data on the former are produced using the Population Register. In other words, their number is calculated as the total of foreign-born Hungarian citizens with valid addresses in the Hungarian national territory, while flow data on the return migration of Hungarian citizens are calculated as the number of re-registrations in the Register of Health Insurance.

- International emigration of Hungarian citizens: the outflow of Hungarian citizens is calculated on the basis of de-registrations ${ }^{10}$ from the Register of Health Insurance (owned by the National Institute of Health Insurance Fund Management). ${ }^{11}$

One of the most important concerns regarding this data production system is the quality of the secondary data sources that serve as the primary input for migration statistics. These quality concerns are particularly relevant when producing emigration and return migration data (Hegedûs-Lados 2017), since - as it was mentioned above - movers often do not de- (and re-) register. In this respect, it should be added that in the framework of an ongoing ESS.VIP ADMIN ${ }^{12}$ project, all administrative sources used by the HCSO, including those used in migration statistics, are being evaluated from a quality point of view.

${ }^{10}$ In a strict sense, emigrants do not de-register, but suspend the validity of their registration. Similarly, returners do not re-register, but request authorities to finalise the suspension of their registration.

${ }^{11}$ Stocks of Hungarian citizens abroad are out of the scope of official migration statistics in Hungary; however, mirror statistics are regularly checked and expert estimations are made (see the section 'International Migration in Hungary' of this paper).

${ }_{12}$ https://ec.europa.eu/eurostat/cros/content/essvip-admin-business-case_en

Regional Statistics, Vol. 7. No. 2. 2017: 101-123; DOI: 10.15196/RS070203 
Another concern is that the available data sources are often inconsistent. As the SEEMIG exercise suggested (see above), their reconciliation and the creation of externally as well as internally consistent data sets based on multiple sources is crucial to produce reliable migration statistics. However, the integrability of different data sources on migration is limited in the Hungarian statistical system due to data protection principles and laws in Hungary. It should be emphasised that the new Statistical Act that recently come into force in Hungary enables the HCSO to ignore those strict regulations of data protection in the future. Considering this reason, it is expected that migration statistics will be based on multiple sources in the next few years.

\section{Conclusions}

Over the last century, in line with intensifying globalisation processes, and new patterns and types of migration, new routes and new migrant identities emerged. In the meanwhile, Europe - after being a migrant sending continent for centuries - has become one of the most popular destinations for migrants globally. Since the regime changes of the 1990s, Central and Eastern European countries - as a result of the economic integration of the continent - have become host areas to migrant population. Hungary today, as part of the global route, is hosting citizens from 168 countries. The role of cross-border mobility - as it was pointed out in this paper - has been playing a considerable role in how the number and composition of the Hungarian population have changed since the 1990s.

In terms of the regional distribution of foreigners, we pointed out that Budapest and Pest County account for a major part, while the micro-regions along the border and the surroundings of Lake Balaton account a smaller part. Budapest is a global destination for migrants accounting for most non-European citizens. Metropolitan areas are primary destinations for migration showing diversity in culture and ethnic composition and providing a wide spectrum of job opportunities. According to our results, in addition to regional differences in earnings, the location of destination areas plays a major role in how the migrants are distributed regionally. When finding a new place to live, beyond economic core areas, neighbouring and border - in this case peripheral - areas play a major role too, where the propensity to migrate has a linear relationship with economic disparities and a reverse one with distances (topographic as well as cultural). According to the traditional approach of location theories, border areas are disadvantaged. There was a change in their situation in the age of global market processes and regional integrations. Border regions are increasingly becoming active contact areas. In case of migration, a geographical 'from-to' matrix type approach enabled us to study migration networks. We found that in addition to the regional differences in earnings, the locations of host areas, as well as the mi-

Regional Statistics, Vol. 7. No. 2. 2017: 101-123; DOI: 10.15196/RS070203 
grant networks played a major role while interpreting the regional distribution of migrants.

Migration is an inherently complex, continually evolving, and potentially sensitive topic with implications for a wide range of socio-economic, demographic, geographic, and public policy areas. Considering this reason, according to the authors of this paper, for a better understanding of international migrations - as the basis for the making well-designed polices - an inter-disciplinary approach is required, that is based on harmonised definitions and methods, links sending, host and transit countries, and can take into account new forms of migration. The role of official statistics in this is to provide high quality empirical evidences for such an approach that deals with the inconsistencies across different data sources and provides the opportunity to jointly examine a series of demographic, socioeconomic, and subjective characteristics of migrants, potential migrants, and nonmigrants. As such, the use of multiple sources, including administrative data sets, surveys, and potentially mirror statistics and Big Data sources is unavoidable, for which the application and methodological development of data integration techniques is foreseen.

\section{Acknowledgement}

This work was supported by the János Bolyai Research Scholarship of the Hungarian Academy of Sciences.

\section{REFERENCES}

Anderson, J.-O’Down, L. (1999): Borders, Border Regions and Territoriality: Contradictory Meaning, Changing Significance Regional Studies 33 (7): 593-604. https://doi.org/10.1080/00343409950078648

CoHEN, B. (2006): Urbanization in developing countries: Current trends, future projections, and key challenges for sustainability Technology in Society 28 (1-2): 63-80. https://doi.org/10.1016/j.techsoc.2005.10.005

BLASKÓ, Zs. (2014): Surveying the Absentees - Surveying the Emigrants SEEMIG Working Papers Series, No. 4, Hungarian Demographic Research Institute, Budapest.

BLASKÓ, Zs.-LigeTI, A. S.-SIK, E. (2014): Magyarok külföldön - Mennyien? Kik? Hol? In: KOLOSI , T.-TÓTH , I. GY. (eds.): Társadalmi Riport 2014. pp. 351-372., Tárki, Budapest.

Castles, S.-Delgado Wise, R. (2008): Migration and Development: Perspectives from the South IOM, Geneva

Castles, S. (2008): Development and Migration - Migration and Development: What comes first? SSRC Migration \& Development Conference Paper No. 2, Social Science Research Center, New York.

DE HAAS, H. (2008): Migration and development - A theoretical perspective International Migration Institute Working papers, No. 9, University of Oxford, Oxford.

Regional Statistics, Vol. 7. No. 2. 2017: 101-123; DOI: 10.15196/RS070203 
De Jong, G. F.-Gardner, R. W (1981): Migration Decision-making, Multidisciplinary approaches to Microlevel studies in Developed and Developing countries Pergamon Policy Studies, Oxford.

EGEDY, T. (2017): A külföldre ingázás statisztikai, demográfiai és területi jellemzői Magyarországon Területi Statisztika 57 (4): 385-405. https://doi.org/10.15196/ ts 570403

FAIST, T. (2008): Migrants as Transnational Development Agents: An Inquiry into the Newest Round of the Migration-Development Nexus Population, Space and Place 14 (1): 21-42. https://doi.org/10.1002/psp.471

GÁBrITY MOLNÁR, I. (2006): Migrációs folyamatok In: GÁBRITY MOLNÁR, I.-RICZ, A. (eds.): Kistérségek életereje - Délvidéki fejlesztési lehetôségek pp. 69-72., Regionális Tudományi Társaság. Szabadka.

GÁrDOs, É. -GÖDRI, I. (2013): Analysis of existing migratory data production systems and major data sources Hungary. Country report developed within the project 'SEEMIG Managing Migration and Its Effects - Transnational Actions towards Evidence Based Strategies'. http://www.seemig.eu/downloads/outputs/ SEEMIGDataSystemsCountryReportHungary.pdf (downloaded: 10.01.2018)

GELLÉRNÉ LUKÁCS, É.-SZIGETI, B. (2005): Munkavállalási szabályok az EU tagállamaiban az átmeneti idó alatt KJK Kerszöv, Budapest.

GÖDRI, I. (2010): A vándorlási veszteség Magyarországon az elmúlt évtizedben - avagy hányan is vagyunk valójában? Korfa 10 (3): 3.

Hatton, T. J.-Williamson, J. G. (2005): Global Migration and the World Economy: Two Centuries of Policy and Performance MIT Press, Cambridge.

ILLÉS, S. (2008): Indirect estimation on the types of international elderly migration in Hungary Romanian Review on political Geography 8 (1): 55-63.

ILLÉs, S.-KINCSES, Á. (2008): Foreign retired migrants in Hungary Hungarian Statistical Review 86 (Special Number 12): 88-111.

Illés, S.-KINCSES, Á. (2009): Cirkuláció és migráció Magyarország nemzetközi vándormozgalmában Statisztikai Szemle 87 (7-8): 729-747.

HANSEN, N. (1977): Border Regions: a Critique of Spatial Theory and a European Case Studies Annals of Regional Science 11 (1): 1-14. https://doi.org/10.1007/ bf01287245

HÁRs, Á. (2009): Immigration countries in Central and Eastern Europe: The Case of Hungary IDEA Working Papers, No. 12. Centre for Migration and Refugee Studies of the Ethnic and National Minority Studies, Institute Hungarian Academy of Sciences, Budapest.

HÁRS, Á. (2016): Emigration and Imigration in Hungary after the Regime change In: BLASKÓ, Zs.-FAZEKAS, K. (eds.) (2016) The Hungarian Labour Market 2016 Institute of Economics, Centre for Economic and Regional Studies, Hungarian Academy of Sciences, Budapest.

HÁRs, Á.-SimON, D. (2015): A munkaeró-migráció változása a kétezres években Magyarországon Budapesti Munkagazdaságtani Füzetek, BWP, 2015/2., Budapest.

Hegedưs, G.-LADOS, G. (2017): A visszavándorlás és az identitásváltozás kapcsolatának vizsgálata a hazatérő magyarok példáján Területi Statisztika 57 (5): 512-536. https://doi.org/10.15196/TS570503

Regional Statistics, Vol. 7. No. 2. 2017: 101 -123; DOI: 10.15196/RS070203 
Horváth, Á. (2016) Return Migrants In: Blaskó, Zs.-FAZEKAs, K. (eds.) (2016) The Hungarian Labour Market 2016 Institute of Economics, Centre for Economic and Regional Studies, Hungarian Academy of Sciences, Budapest.

KAPITÁNY, B.-ROHR, A. (2013): A Magyarországon állandó lakcímmel rendelkező 18-49 éves magyar állampolgárok mintegy 7,4 százaléka tartózkodik jelenleg tartósan külföldön Korfa 13 (3): 3.

KINCSES, Á. (2012): A Kárpát-medence ezredforduló utáni migrációs hálózatának vizsgálata $\mathrm{KSH}$, Budapest.

KINCSES, Á. (2015): International Migration Diversity in Hungary in the 2011 Population Census Data Regional Statistics 5 (2): 108-124. https://doi.org/10.15196/ ts05206

KINCSES, Á.-BÁLINT, L. (2016): Migration settlement networks in the Carpathian Basin, 2001-2011 Regional Statistics 6 (2): 95-113. https://doi.org/10.15196/rs06205

Kofman, E.-Youngs, G. (2003): Globalization: Theory and Practice Continuum, New York.

KósA, D. (2016): Ukranian Migration in Hungary Foundation of Subjective Values, Budapest. http://www.szubjektiv.org/wp-content/uploads/2016/02/migrationreport-1.pdf

KŐszeghy, L. (2010). Külföldiek Budapesten In: HÁrs, Á.-TóTH, J. (eds.): Változó Migráció-Változó Környezet pp. 221-243., KI, Budapest.

KSH (2016): Demográfiai évkönyv, 2016 Budapest.

Massey, D. S.-Arango, J.-Hugo, G.-Kouaouci, A.-Pellegrino, A.-Taylor, J. E. (1998): Worlds in Motion. Understanding International Migration at the End of the Millennium, Clarendon Press, Oxford.

MCHugH, K. E. (1995): Multiple residence and cyclical migration: a life course perspective Professional Geographer 47 (3): 251-267. https://doi.org/10.1111/j.00330124.1995.00251.x

MC Loughlin, S.-MÜnZ, R.-BÜNTE, R.-Hultin, G. -MÜlleR, W.-Skeldon, R. (2011): Temporary and circular migration: opportunities and challenges European Policy Centre, Brussels.

MoreH, C. (2014): A Decade of Membership: Hungarian Post-Accession Mobility to the United Kingdom Central and Eastern European Migration Review 3 (2): 79-104.

Nijkamp, P. (1998): Moving Frontiers: a Local-global Perspective Research Memorandum No. 22. Vrije Universiteit of Amsterdam, Faculty of Business Administration and Econometrics, Amsterdam.

RÉDEI, M. (2007): Mozgásban a világ, a nemzetközi migráció földrajza Eötvös Kiadó, Budapest.

SALT, J. (2001): European migration field. In: Demographic and Cultural Specificity and Integration of Migrants pp. 13-44., Bundesinstitut for Population Research in co-operation with the Network of Integrated European Population Studies. Wiesbaden, Germany.

SEEMIG (2014): A SEEMIG - Managing Migration in South East Europe transznacionális együttmúködési project „Helyzetkép a magyarországi elvándorlásról” címú sajtótájékoztatójának sajtóanyaga https://www.ksh.hu/docs/szolgaltatasok/ sajtoszoba/seemig_sajto_reszletes.pdf

Regional Statistics, Vol. 7. No. 2. 2017: 101-123; DOI: 10.15196/RS070203 
SIK, E.-ÖRKÉNY, A. (2003): A migrációs potenciál kialakulásának mechanizmusa In: ÖRKÉNY, A. (ed.): Menni vagy maradni? Kedvezménytörvény és migrációs várakozások pp. 188-202., HAS Institute for Minority Studies - Research Centre for International Migration and Refugee Affairs, Budapest.

SIK, E.-SZEITL, B. (2016): Migration intentions in contemporary Hungary In: BLASKÓ, Zs.FAZEKAS, K. (eds.): The Hungarian Labour Market 2016 Institute of Economics, Centre for Economic and Regional Studies, Hungarian Academy of Sciences, Budapest.

SISKA-SZILASI, B.-KÓRÓDI, T.-VADNAI, P. (2016): Measuring and interpreting emigration intentions of Hungarians Hungarian Geographical Bulletin 65 (4): 361-369. https://doi.org/10.15201/hungeobull.65.4.5

Skeldon, R. (2012): Going Round in Circles: Circular Migration, Poverty Alleviation and Marginality International Migration 50 (3): 43-60. https://doi.org/10.1111/ j.1468-2435.2012.00751.x

TANNENBAUM, M. (2007): Back and forth: immigrants stories of migration and return International Migration 45 (5): 147-175. https://doi.org/10.1111/j.14682435.2007.00430.x

TÓTH, P. P. (2005): A szomszédos országokból bevándorlók lakóhelyi és kulturális jellemzői Korfa 5 (2-3): 3-7.

Traistaru, I.-Nijkamp, P.-Resmini, L. (2002): The Emerging Economic Geography in EU Accession Countries European Communities, Brussels.

UN General Assembly (2016): Draft resolution referred to the high-level plenary meeting on addressing large movements of refugees and migrants by the General Assembly at its seventieth session. 13 September. http://www.un.org/ga/search/ view_doc.asp?symbol=A/71/L.1

VAn Geenhuizen, M.-RAtTi, R. (2001): Gaining Advantage from Open Borders. An active Space for Regional Development Ashgate, Aldershot.

Venables, A. J. (1998): The assessment: trade and location Oxford Review of Economic Policy 14 (2): 1-6. https://doi.org/10.1093/oxrep/14.2.1

Williamson, J. G. (2006): Global Migration Finance and Development 43 (3): 11.

Regional Statistics, Vol. 7. No. 2. 2017: 101 -123; DOI: 10.15196/RS070203 